\title{
Analysis on the Penetration of the Development of Anglo-American Literature into Humanistic Thoughts
}

\author{
Ma Lina \\ Shaanxi Xueqian Normal University, Xi'an, China, 710100
}

Keywords: Anglo-American literature; development; humanistic thought; penetration

Abstract: In recent years, the level of economic globalization has been continuously improved, and economic cooperation and communication among countries around the world have gradually increased. Communication in politics, education, and literature has also increased. The Chinese people do not know much about Anglo-American literature, although some people read a large number of Anglo-American literature works, but do not have a deep understanding of Anglo-American cultural connotations. This paper analyzes the meaning of Anglo-American literature, the spiritual value and practical significance of Anglo-American Literature, and studies the penetration of English and American literature into humanistic thought.

\section{Introduction}

With the increasing economic and cultural exchanges between countries, the Anglo-American literature has exerted certain influence on all countries in the world, and it has certain promotion and leading role in the development of world literature. Many Anglo-American literary works are well-known works, and formed its unique culture. The literatures of different nationalities and countries have their specific connotations and functions, and their development process is different. The development of Anglo-American culture has certain reference significance for the development of Chinese literature.

\section{Anglo-American Literature Overview}

\subsection{Definition of Anglo-American literature}

Literature is the use of language, words to fully express the author's emotions and feelings, but also to fully show the social reality of the situation, through the text to show the real life of the people. In addition, literature can fully demonstrate the author's understanding and thinking about life, and the author's work can fully display the author's outlook on life and values. By understanding and learning Anglo-American literature, we can fully understand the customs, historical culture, religious beliefs, economic development, and political knowledge of Western countries. 


\subsection{The Spiritual Value and Practical Significance of Anglo-American Literature}

\subsubsection{The Spiritual Value of Anglo-American Literature}

\subsubsection{Humanistic Value in Anglo-American Literature}

In the process of development of Anglo-American literature, a large number of literati, celebrities and many literary works have been produced. Many people think of Shakespeare's "Romeo and Juliet" and "Hamlet" when they think of English literature. "Romeo and Juliet" tells the story of the love between the daughter of the Italian nobleman Capulet, Juliet, and the son of Montagu, Romeo, being obstructed by two families. Two families belong to the hostile family, two parents do not support the love of two people, Juliet and Romeo pursue the love and use their lives to fight against the family. After the two died, the two parents realized that their thoughts were wrong, and then the two returned to good. From this we can discover the positive value of humanism. Hamlet is a masterpiece of Shakespeare, and it is also a tragic work. The character of the protagonist Hamlet is more complicated, he received the news of his father's death when he attended university in Germany, and when he returned to funeral, he received the news that his uncle was married to his mother and his uncle took the throne, which hit Hamlet hard and issued the question of "survival or destruction". Later, Hamlet confirmed that his uncle was the murderer of his father by "playing in the drama." As Hamlet mistakenly killed Bolognes, he accepted the duel request of Leotis. During the duel between the two men, Hamlet's mother died by mistakenly drinking poisoned wine, and Hamlet commissioned Horatio to tell future generations of his story after killing his uncle before he died of poisoning. Throughout his work, Shakespeare criticized feudalism and expressed his dissatisfaction with the existing social system, which was widely disseminated in the Anglo-American region.

\subsubsection{Rationalist Value}

The main writers who can represent the value of rationalism in Anglo-American literature is Saul Bellow, whose main works are: "The Dangling Man", "The Victim", "The Adventures of Oggie March", etc., and many of its works can fully show the value of rationalism. The work of Saul Bellow is the protagonist's thinking and exploration of his destiny. Professor Benno, the protagonist in his work "More People Die in Heartbreak", chooses to escape to his own plant kingdom when he discovered that the world of love and consideration he was pursuing was a trap of money and desire, and finally fled to the North Pole, hoping to forget his pain through plant research. The protagonists in Saul Bellow's works want to pursue a beautiful life, but the actual life is the opposite, and they choose to escape after being hurt. They expect to be respected characters, but in real life they are only victims, and the contradiction between ideal and reality has always existed. In the works of Saul Bellow, we can understand the development of American society in the 20th century, the economic development, and guide people to think about the impact of social development on the development of human morality.

\subsubsection{Black Humor Value}

Black humor refers to a comedy that combines pain, laughter, cruelty, tenderness, etc., which belongs to an absurd, pathological literary style. The author mainly reflects his unfair treatment and social phenomena in his works, and uses a mocking way to vent his dissatisfaction with the society, and people can fully feel the author's dissatisfaction and helplessness while reading the works. The American writer Thomas Pynchon's work "The Rainbow of Gravity" (its work contains a lot of social information, its style is more unique, its novels mainly involve American history, human 
history, natural sciences, military science, informatics and other knowledge), The protagonist William Slosop was defined as a pagan in the process of justice for the people. This novel fully demonstrates the tragic fate of the protagonist and expresses the author's dissatisfaction with the reality of the social system.

\subsubsection{The Practical Significance of Anglo-American Literature}

Anglo-American literature is the essence of Western social culture, and it is also the ideological crystallization of many Anglo-American writers. When we read and understand English and American literature, we can understand and master the history of the development of the Anglo-American society and the course of human development, think and reflect on our own ideological and moral and social life in a more rational and vivid writing, and constantly improve our thinking ability and imagination ability, so as to help readers establish a correct outlook on life and values.

\section{An Analysis of the Development of Anglo-American Literature}

\subsection{The Development of British Literature}

\subsubsection{Humanism-centered stage}

In medieval Western Europe, the church was the main force in controlling and mastering society. It established a strict hierarchy to control and restrain people, and wrote a large number of literary works to control people's thoughts to instill their literature. In the 14th century, capitalism began to sprout, and social productivity increased rapidly. Italy began the Renaissance, and the Renaissance developed from the rise of Italian cities to various countries in Western Europe. The Renaissance not only promoted the development of literature, but also promoted the technological revolution. During the Renaissance, there were many literary writers in Western Europe, such as Shakespeare, Thomas Moore, and Francis Bacon, and created a large number of literary works. Most of the literary works at this stage are against the church dictatorship and the pursuit of spiritual freedom. By reading Thomas Moore's work Utopia, we can fully understand its yearning for and pursuit of spiritual freedom.

\subsubsection{The stage of pursuing neoclassical}

As early as the 15th century, the United Kingdom began to conduct overseas trade. With the gradual rise of overseas trade, many new aristocrats gradually formed. Their development direction and needs contradicted the interests of the feudal dynasty, and they often contradicted the church. In 1640, the British broke out of the bourgeois revolution and determined the bourgeoisie's dominance. At this stage, mainstream literature is the pursuit of neoclassical literature. During this period, a large number of literary works emerged, the most typical of which is John Bunyan's "The Road to Heaven". The book is divided into two parts, the first half of which describes "I" in the dream to see a person called "Christian" is reading, and he knows that his place of residence will encounter sky fire. At this time, a person named "Evangelist" instructed him to flee his hometown and go to the disaster-free heaven. From then on, the "Christian" stepped into the search for the kingdom of heaven to find a path of salvation for themselves and others; the second half was about the hard journey of his wife and children to heaven under the guidance of a man named "Fearless".

The purpose and process of the two journeys are very similar, and the protagonists have experienced various difficulties and obtained redemption. In 1840, with the beginning of the industrial revolution, the Anglo-American literary works at this stage were also affected. The 
literary works created at this stage not only contain the concept of science and technology, but also raise the importance of environmental protection, and discuss the harm of paying too much attention to economic interests.

\subsection{The Development of American Literature}

\subsubsection{A stage dominated by church essays}

In 1607, Britain established Jamestown on the Chesapeake Beach in the Americas, which was the first colony established by the United Kingdom in North America. In the following 150 years, Britain, France, Germany and other countries established several colonies in the Americas. In the 18th century, the United Kingdom established 13 colonies in the Americas and established the government and parliament with the support of the British government. The British government squeezes the local people in pursuit of more interests. One of the main methods adopted by the United Kingdom is to use religion to control the ideas of the local people. Therefore, most of the American literary works in this period are the diary of the British, and it contain a lot of religious ideas. Michael Wiggs's work, Judgment Day, is mainly about the control of people's thoughts by religion, so that the work can fully understand the local customs, traditions, and people's living conditions.

\subsubsection{The emergence and development of national literature}

Because the people of North America were oppressed by British colonial rulers, and with the continued development of the colonial economy, in 1775 Lexington, Massachusetts began to rebel against British colonial rule; in May 1776, a continental conference was held in Philadelphia, and released Declaration of Independence. Under the constant efforts and struggle of the people of North America, Britain signed the Paris Peace Treaty in 1782; until 1783, Britain recognized American independence. Although the two countries had great disparity of power, the people of North America finally won the war. The Declaration of Independence belongs to the important literary works of the United States during this period. It mainly promotes peace, unity and freedom, and expresses that the rights of the rulers must be given by the people.

\subsubsection{The stage of romanticism and realism}

The American War of Independence has fully eliminated all kinds of obstacles to the development of capitalism, after the political stability, capitalism has also developed rapidly, the Southern plantation economy has also made great progress, the people's income has increased, the quality of life has been improved. In this context, romantic literature was formed. In this kind of literary works contains a large number of subjective color and blocking imagination, which are rich in creation and have the beauty of nature. At this stage, Walt Whitman, Ralph Waldo Emerson and others belong to the romantic writer. Ralph Waldo Emerson's work "On Nature" fully demonstrates the romantic style of this stage, which analyzes a large number of natural materials and analyzes the new order and life of human society. In the late 19th century, American literature turned to realism, and many writers began to attach importance to the problems existing in life, such as: the living conditions of farmers, the suffering of the people at the bottom, and so on. Many writers have expressed their own living conditions in their works and their critique of the status quo of society. 
4. The Penetration of the Development of British and American Literature on Humanistic Thoughts

\subsection{The Penetration of Anglo-American Literature Development Into Western Humanistic Thoughts}

From a narrow perspective, Western humanistic thinking refers to the ideological trend that gradually emerged during the Renaissance; from a general perspective, Western humanistic thinking refers to a cultural tradition formed and passed down in ancient Greece and Rome.

The core of Western humanistic thought is people-oriented, and there are fewer literary works that will influence humanistic thought in the early society, most of the works at this stage are speeches. With the continuous development of human society, the Anglo-American literary works which have an impact on humanistic thought have gradually increased. As can be seen from the above, the literary works created by writers are closely related to their historical periods, and the styles of literary works are not the same in different historical periods, and these literary works may fully demonstrate the social development, historical situation and social system at this stage. Most of the Anglo-American literatures are realist literary works. We can read the Anglo-American literary works to understand the social development and social system at that time, and at the same time promote people's transformation of ideas and building a harmonious society.

\subsection{The Penetration of Anglo-American Literature Development Into China's Humanistic Thoughts}

In recent years, the economic activities and cultural exchange activities between China and Western countries have gradually increased. The development of Anglo-American culture has also formed a certain infiltration effect on China's humanistic thought, which has had a certain impact on young people's outlook on life and values. As the speed of economic globalization continues to accelerate, Chinese literature has been greatly influenced by Anglo-American literature. Compared with other countries, China's culture has a strong inclusiveness, We can learn and draw lessons from the artistic and charm characteristics of Anglo-American literature, and promote the sustainable development of Chinese literature.

The penetration of Anglo-American literature into China's humanistic thought is mainly divided into the following stages: the early 20th century, the mid-20th century, and the end of 20th century to the present. As early as the beginning of the 20th century, China began to transform into a modern society. Under this background, traditional literature can no longer meet the needs of social development and people's needs. Chinese literature needs to be transformed and developed. Therefore, in the 20th century, China's literature began to develop towards an open perspective, Anglo-American literature has gradually entered China. Although many writers in China began to learn and quote Anglo-American literary creation methods at this stage, but British and American literature did not have a great influence on Chinese literature at this stage; In the mid-20th century, before and after the founding of New China, Anglo-American literature also did not have a tremendous impact on Chinese literature; After the implementation of the reform and opening up policy in the late 20th century, Anglo-American literary works began to enter China in large numbers. At this stage, Anglo-American literary works have a great influence on Chinese literature, and have a certain influence on the Chinese people's thoughts. Nowdays, cooperation and cultural exchanges between countries are gradually increasing. However, in the process of integration with Chinese literature, Anglo-American literature will not only form a positive impact, but also form a certain negative impact. Therefore, we need to pay attention to the influence of Anglo-American literature on our people's thoughts, enlarge the positive influence of Anglo-American literature on 
our people's thoughts, and reduce or even eliminate the negative impact of Anglo-American literature on our people's thoughts. In order to achieve this goal, our country needs to face up to the penetration and influence of Anglo-American literature on China's humanistic thought, actively study the advantages of Anglo-American literature, organically integrate British and American literature with Chinese literature, and promote the stable and healthy development of Chinese literature.

\section{Conclusion}

In short, literature will affect people's values, outlook on life, but also affect the social ethos and national development. In order to avoid the negative influence of literature on the development of the country, it is necessary to strictly control literary works, the main purpose of which is to create a good literary environment. This paper analyzes the penetration of Anglo-American literature into humanistic thoughts. All literatures will have an infiltration effect on humanistic thoughts. Therefore, we need to analyze the positive significance of all literary works to the social development of our country.

\section{References}

[1] Liu Jiao. The Teaching of Anglo-American Literature and the Infiltration of Humanistic Thoughts [J]. Literature Education: Middle, 2016(9):68-68.

[2] Li Meng. Exploring ways and means to improve the penetration of humanistic thoughts in Anglo-American literature teaching [J]. Journal of Hubei Correspondence University, 2016, 29(18):102-103.

[3] Liu Lulu. Exploring the teaching of Anglo-American literature and the infiltration of humanistic thoughts [J]. Modern economic information, 2017(21):390-390.

[4] Nie Haiyan. How to infiltrate humanistic thoughts in the teaching of Anglo-American literature [J]. Northern Literature: Middle, 2017(9):170-170

[5] Shu Dazhong. On the teaching of Anglo-American literature and the infiltration of humanistic thoughts [J]. Era education, 2016(13):156-156.

[6] Ren Jing. The infiltration of humanistic thoughts in the process of college Anglo-American literature teaching [J]. Journal of Suzhou Education College, 2016, 19(1):115-116. 